\title{
居住地選択とその評価指標に関する様相論的分析

\author{
ANALYSIS ON RESIDENTIAL LOCATION CHOICE AND \\ ITS EVALUATION INDEXES BASED ON MODAL THEORY
}

\author{
北雄 介* \\ Yusuke KITA
}

\begin{abstract}
The goal of this study is to build a method for giving information about the atmosphere of each city or area to house-hunters and evaluate residential location precisely for future urban planning. We introduced the concept of "modality," which means "total mode of being" and analyzed residential location choice using a questionnaire. The major results of this paper are as below:

1. Evaluation indexes regarding the atmosphere are important in choosing residential location beside other existing indexes like convenience and function.

2. Conditions like sexuality, age, family structure, and house ownership are strongly related to residential location choice.

3. The tendency towards residential location choice depends on the urban scale and area type.
\end{abstract}

Keywords : Residential Location Choice, House-H unting, U rban M odality, Residential Condition, Time Series Analysis 居住地選択，住まい探し，都市の様相，居住条件，時系列分析

\section{1. はじめに}

\section{1. 研究の背景}

本研究の実践的背景として、住まい探しにおける情報の不足があ る。現在われわれが住まいを探すとき、不動産業者を直接訪れるか、 不動産情報サイトで検索するのが一般的な方法である。そこで得ら れるのは主に物件に紐付けられた情報であり、その物件の所在する 都市・地域について知ることは難しい。業者やサイトで地域の統計 情報などが提供されることはあるが、物件の周辺環境の雾囲気や居 心地など、数字では表現されない漠然としたことがらも数多い。特 にその地域になじみがない者にとっては、そうした側面も住まい探 しの際の重要なポイントになるのではないかと考えられる。

地域の雲囲気のようなことがらを、住まい探しのための情報にす ることは可能であろうか。地域をよく知る人々の実感を集合知とし て提示することができれば、地域になじみのない人の住まい探しの 際にも役立つ情報となるであろう。

次により大きな社会的文脈として、わが国の人口減少や空き家の 増加がある。今後、都市や地域は厳しい選択の目に晒される。人口 の大半を失い衰退寸る都市や地域も発生してくることであろう。

その中で、人々にとって住みやすい都市や地域とはどのようなも のであろうか。人々は現在の居住環境をどのように感じ、また将来 どのような環境を選び取るのであろうか。都市や地域の持続性を担 保するためには、これまでの居住環境の在り方を正しく評価し、今 後の動向を予測した上で、これからの計画に活かしてゆかなければ ならない。コンパクトシティや中心市街地再開発など、トップダウ
ンの都市再編論ももちろん必要であるが、その一方で居住者の実感 に根ざした居住地選択に関しても研究を進める必要がある。このよ うな視点からも、雾囲気や居心地などを含んだ総合的な見地から居 住環境を評価する方法論が必要である。

\section{2. 様相論的研究とその方法}

以上の背景に対し、本研究では椂相論の立場で居住地選択につい て研究する。「様相(modality)」という概念はアリストテレス以来の 歴史をもち、定義も多様である。それらに共通寸る考え方は、何か の存在物自体ではなく、その「在り方」を指寸ということである。 特に様相論理学では「可能」と「必然」という二つの在り方を中心 に、様相が定式化されてきた。原広司は様相の概念を建築・都市分 野に導入し、「事物の状態や空間の状態の見えがかり、外見、あらわ れ、表情、記号、雰囲気、たたずまいなどと表記される現象」を様 相と呼んでいる11。本研究ではこの考え方を導入し、様相という語 を、「ものごとの全体的な在り方」を指すものとして用いる。すなわ ち「都市の様相」とは「都市の全体的な在り方」のことを指す。

都市の様相は極めて全体的で漠然としており、また刻々と変化し ているために、人によって捉え方が異なる。筆者はこれまで、多く の被験者に実際に街を歩いてもらい、その場で把握した様相を用紙 に記録してもらう「経路歩行実験」を用いて、都市の様相について の研究を行なってきた ${ }^{2}$ 。多数の記録を集約することで、様相把握と いう属人的で漠然とした対象を、分析的に、またある程度一般化し て論じた。その中で筆者は、様相把握において重要な役割を果たす、 記憶や期待を生み出す心的モデルを「フレーム（frame）」と呼んで
* 京都大学学際融合教育研究推進センターデザイン学ユニット 特定講師·工博
Lect., Unit of Design, Center for the Promotion of Interdisciplinary Education and Research, Kyoto Univ., Dr.Eng. 
いる3）。フレームは認知科学や人工知能の分野で頻繁に用いられる 概念である。本研究では、出来事や知識を構造化して蓄積し、それ をもとに次に起きることを予想し、また自らが何をなすべきかを判 断する心的機構として措定する。

以上の理論を居住地選択というテーマに適用し、人が居住地を選 択する際の一般的プロセスを、本稿では以下のように仮定する。

人はある属性をもっている。人は日々生活する中で、自分の居住 地やその他の場所において、常に何らかの様相を把握し、それを記 憶として蓄積している。あるときに居住地選択の機会が訪れるが、 その際には同居する家族や勤務地のような居住条件が、居住地選択 に制約をかける（ただし居住条件は必ずしも外部から与えられると は限らず、自ら設定することもできる)。そして人は、自らの属性、 これまでの記憶、居住条件、好みなどを踏まえた総合的な判断によ り、具体的な居住地を選択する。フレームは、様相把握、居住地の 記憶、居住条件の取り込み、居住地の選択というプロセス全体を下 支えする役割を果たす。

そしてこのような居住地選択行動を研究するため、本研究は以下 のような研究方法を採る。

(1)居住地の評価基準を総合的に分析する（交通利便性や店舗の量な ど既にある定量的に表わしうる基準も、雲囲気や居心地のような 定量化しづらい基準も、両方を扱う)

(2)都市や地域を単独で扱うのではなく、その周辺を含む文脈の中で 相対化して捉える。

(3)様相がどのように把握されるかは、その場の状況だけではなく、 その人のフレームに大きく依存する。よって各人の居住経験や、 新しい住まいを探す際の条件など、居住地選択の背景を読み込む。

\section{3. 本稿の目的と研究手法}

本稿は居住地選択の様相論的研究の初期段階に位置し、居住地選 択傾向の概要を明らかにする。具体的には以下の各項を目的とする。 - 居住地選択にかかわる人の属性や居住条件を整理し、それらと居 住地選択の傾向との関係を明らかにすること。

・これまでにどのような居住地が選択され、またその傾向は今後ど のようになるのかを明らかにすること。

・人が居住地に対して把握する様相をよく表現するような、代表的 な言語指標を抽出すること。その指標は、居住地の評価や住まい 探しの際の情報としても有効になりうる。

これらの目的を、前節で挙げた(1)〜 (3)の方法論によって探求する。 具体的な手法としては、アンケート調査によって住まい探しにおけ る人々の実感に関する多量のデータを取得し、統計的に分析する。 調査にはウェブ上のクラウドソーシングサービスである「Yahoo!ク ラウドソーシング」注1）を利用した。本研究は特定の都市や地域を対 象とせず、わが国の居住環境一般について論じるため、日本全国の 居住者から広くデータを得るには面接法や留置法などではなくウェ ブ調査が適している。その中でもクラウドソーシングは、多量のデ 一タを短期間にローコストで入手できる点においてすぐれている。 クラウドソーシングのサンプル特性やデータの取り方に関しては、 清水ら4）を参照した。

\section{4. 既往研究と本研究の位置づけ}

居住地選択に関する研究としては、26の評価指標を用いたコンジ ヨイント分析によって住民の転居動機の類型化をした西山らの研究
5）や、大学周辺の学生の地理的分布とその評価構造を分析した鶴崎 らの研究6) などがある。これらの研究では、居住地の評価指標とし て生活利便性や安全性などの機能的指標を重視しているが、本研究 は雰囲気などの諸指標にも焦点を当てる。また都市や地域という空 間スケールや、現在-将来という時間軸といったより広いコンテクス 卜の中で居住地選択を考える。その意味では、本研究は立地論や人 口動態論とも関係する。

䨌囲気に関する多数の評価指標を用いた研究は、環境心理学分野 や、景観や街路空間の分析において展開されている（船越ら7）など）。 本研究では空間体験者としてではなく居住者としての視点を導入す る。またこれらの研究では心身二元論的立場がとられることが多い が、本研究では様相論に基づいた研究方法を提示する。

居住地ではなく住居の選択に関する研究も行なわれている。たと えば室らは、評価用語の選定のために100の語を用いて研究してお り8)、本稿でも評価指標構築の際に参照する。

\section{2. データの取得}

\section{1. 調査設計}

上述の目的に応じ、既往研究を参考にしながら調查設計を行なっ た。その項目の一覧を表 1 に記す注2)。今後、表内「項目名」に当た る言葉を【】で、項目内の選択肢に当たる言葉を［]で表わす。

「属性」「居住条件」「居住地」「評価指標」という大きく四つの力 テゴリーで、また「現在」と「将来」に分けてデータを取得するこ ととした。居住条件、居住地は現在・将来ともに共通の質問項目と し、時系列比較を可能としている。属性は【住まい探し可能性】を 除けば現在のみ、評価指標は将来のみにかかる項目である。

評価指標は53を選定した注3)。利便性や諸施設の有無といった、地 図や統計データ等から客観的に把握が可能な従来的指標と、雰囲気 やたたずまいに関連する、主観的でこれまで住まい探しの情報とし て提供されてこなかった指標の両方が含まれる。本稿では、前者を 【A群】、後者を【B群】の評価指標と呼ぶこととする注4)

\section{表1 調査項目の一覧}

\begin{tabular}{|c|c|c|c|c|}
\hline 大分類 & 現在 & 将来 & 項目名 & 質問形式 \\
\hline 属性 & 0 & $\triangle$ & $\begin{array}{l}\text { 【性別】年齢】【職業】(現 } \\
\text { 在) } \\
\text { 【住まい探し可能性】(将 } \\
\text { 来) }\end{array}$ & $\begin{array}{l}\text { 性別/年齢/職 業: あなたの〜 } \\
\text { 〜を教えてください。(択一) } \\
\text { 住まい探し可能性: } 3 \text { 年以内に } \\
\text { 住まい探しをする可能性があり } \\
\text { ますか?(択一) }\end{array}$ \\
\hline 居住条件 & 0 & 0 & $\begin{array}{l}\text { 【居住人数】【同居者構 } \\
\text { 成】自家用車所有台数】 } \\
\text { 【通勤·通学時間】オオーナ } \\
\text { ーシップ】【建物類型】 }\end{array}$ & $\begin{array}{l}\text { 現在 : 現在のお住まいは、どの } \\
\text { ような〜〜〜ですか? } \\
\text { 将来 : 次に住まいを探す場合、 } \\
\text { どのような〜〜〜を想定してい }\end{array}$ \\
\hline 居住地 & 0 & O & 【都市規模】【地域類型】 & $\begin{array}{l}\text { ますか? (【同居者構成】のみ } \\
\text { 複数回答可、他は択一) }\end{array}$ \\
\hline 評価指㮌 & - & O & $\begin{array}{l}\text { 【A群】17指標 } \\
\text { 【B群】36指標 }\end{array}$ & $\begin{array}{l}\text { 次に住まいを探す場合、その住 } \\
\text { まいが以下のような地域にある } \\
\text { ことを重視しますか？(5段階) }\end{array}$ \\
\hline
\end{tabular}

\section{2. データの概観}

調査は2016年1月に行ない、無効な回答を除いて 1,244 のサンプル を得た注5)。属性データのうち 3 項目の構成を図 1 に示す注6)。【年齢】 については 20 代後半-40代がボリュームゾーンとなっており、日本 の年齢構成と比べても、20代前半以下や50代後半以上のサンプルが 少ない。【性別】は全体としてはバランスが取れているが、女性より 
も男性の年齢層が高い。【住まい探し可能性】は若年層ほど高い。

アンケート調查を用いた研究一般に言えることであるが、本研究 で得られる知見はサンプルの制約下のものとなる。ただし十分なサ ンプル数が得られており、また 20 代後半-40代は経済的にも自立し、 ライフステージの変化に応じた住み替えも増えると考えられること から、われわれの居住地選択一般について分析するために適切なサ ンプルであると筆者は考えている。

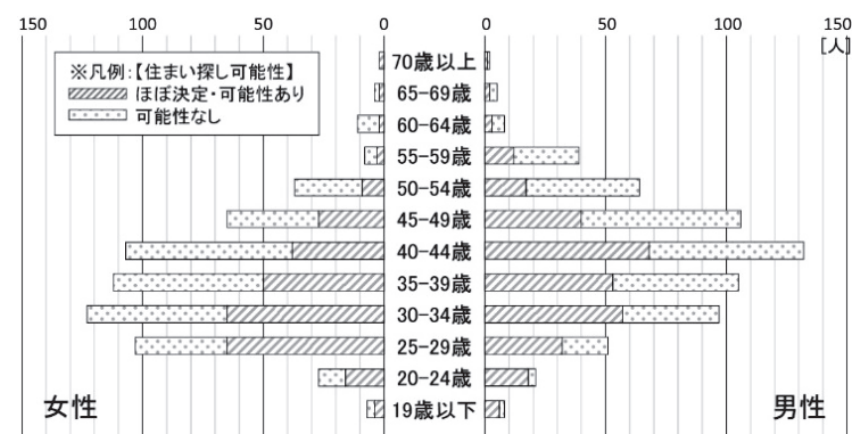

図1【性別】【年齢】【住まい探し可能性】の構成

また【住まい探し可能性】がないとする回答者が半数以上あった。 居住地選択について感度の低いサンプルとなる恐れがある。しかし 図1にあるように住まい探しの可能性のない人は高年齢の人ほど多 く、また下の表 2 に示寸ように現在の持ち家比率が高い。一般的に賃 貸は転居サイクルが短いのに対して、住宅購入は一生に一度とも言 われ、既に住宅購入を住ませている人は住まい探しの可能性がない ことが多い。しかし持ち家居住者もそれぞれに住まい探しの判断基 準は備えている。また【住まい探し可能性】があるとした回答だけ に分析対象を限定すると、持ち家購入時の居住地選択の分析が難し くなる。したがって本稿では、【住まい探し可能性】の有無にかかわ らず、有効なデータとして扱う。

表2【住まい探し可能性】と【オーナーシップ】のクロス集計

\begin{tabular}{|l|l|r|r|r|}
\hline \multicolumn{2}{|c|}{} & \multicolumn{3}{|c|}{ 現在の【オーナーシップ】 } \\
\cline { 3 - 5 } \multicolumn{2}{|c|}{} & 持ち家 & \multicolumn{1}{c|}{ 賃貸 } & \multicolumn{1}{c|}{ 合計 } \\
\hline \multirow{3}{*}{ 【住まい探し可能性】 } & ほぼ決定・可能性あり & 257 & 335 & 592 \\
\cline { 2 - 5 } & 能性なし & 503 & 149 & 652 \\
\cline { 2 - 5 } & 合計 & 760 & 484 & 1,244 \\
\hline
\end{tabular}

\section{3. 分析の流れ}

取得データは多岐に渡り、現在・将来という時間軸も含んだ複雑 なものである。そこで、これらを同時に扱うのではなく、評価指標、 属性と居住条件、居住地と、それらの間にある関係を順々に分析し てゆく。3章では評価指標データを概観し、4章以降の分析の素地を つくる。4章では、属性、居住条件を分析するとともに、評価指標と 照らして、どのような人が、どのような言葉で表現される居住地を 選択するのかを分析する。 5 章では、居住地と評価指標との関連性を 分析する。

\section{3. 評価指標データの分析}

図2は、53の評価指標の5段階評価值の平均值と標準偏差を、平均 值の降順で整列したものである。

3.1. 平均値について

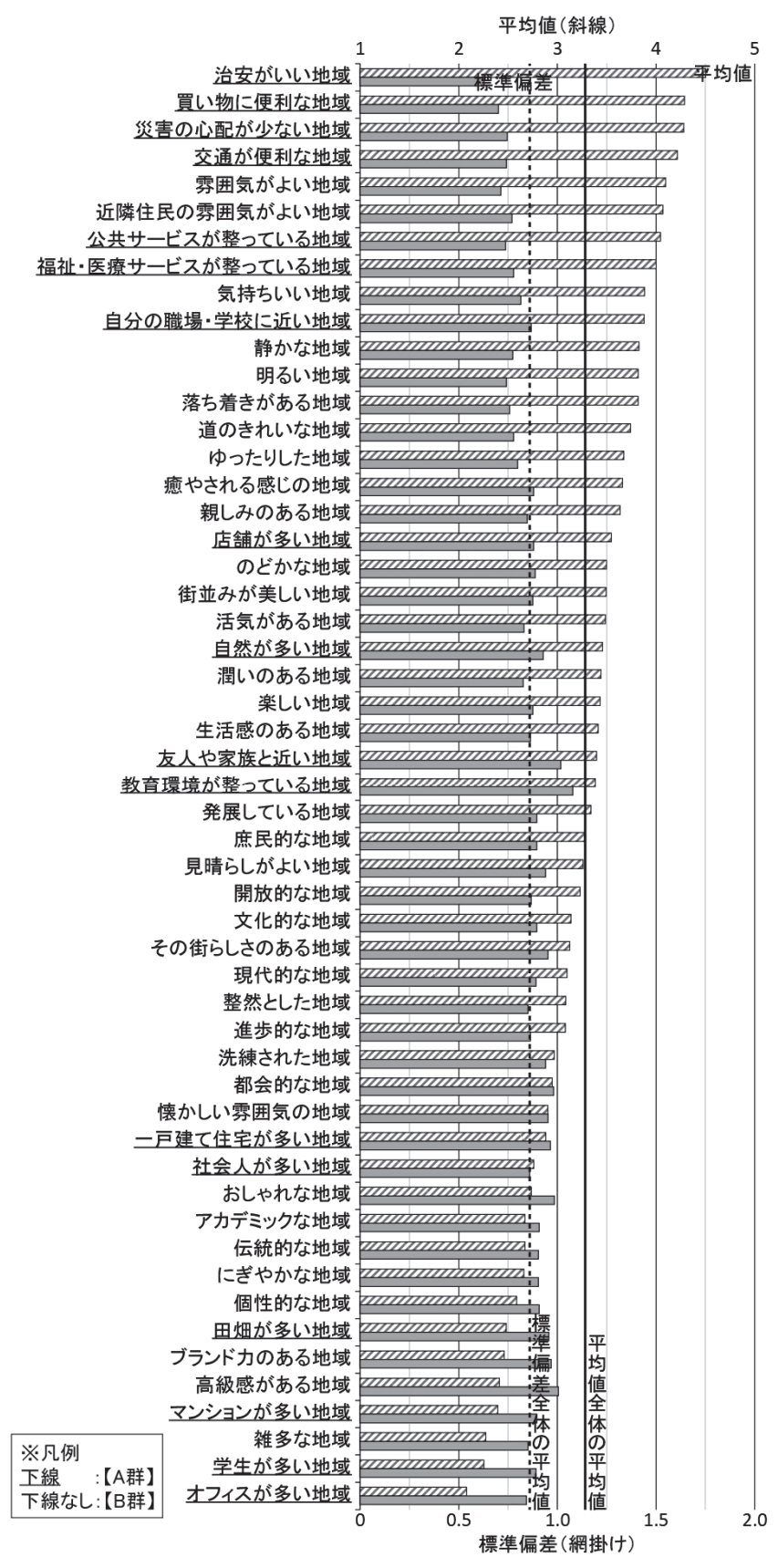

図2 指標の平均値および標準偏差

【A群】では[治安がいい地域] [買い物に便利な地域][災害の心配が 少ない地域][交通が便利な地域][公共サービスが整っている地 域][福祉・医療サービスが整っている地域]などが、住まい探しの重 要な基準であることが伺える。このうち交通機関やサービス施設な ど生活機能の配置に関しては不動産情報として提供されることが多 い。しかし犯罪や災害に関してはハザードマップとして危険性の分 布が一般公開されているものの、不動産業者は住まい手に提供しな いことが一般的で、情報の非対称性が生じている。

一方で、【A群】でも「○○が多い地域」として表現される指標は、 [店舗が多い地域][自然が多い地域]を除いて、一戸建て住宅、マンシ ヨン、田畑、オフィスなどは下位に位置する。これらは生活上の必 要性が低く希少性もない、一般的土地利用に関する指標であるため だと考えられる。

次に【B群】では、総合的な指標である[雾囲気がよい地域]が全体 
で5番目に位置するのを始め、[近隣住民の雾囲気がよい地域][気持 ちいい地域] 静かな地域] 明るい地域]などが上位に入る。客観性の 高いデータだけではなく地域の全体的な雾囲気も住まい探しにおい て重視されることが示され、1.1.で述べた問題意識を裏付けている。 その中で、[静かな地域]や[落ち着きがある地域]などと、[活気が ある地域][楽しい地域]などの、互いに反対の意味を表わすと考えら れる評価指標がともに上位にある。これらはSD法を用いた研究にお いて通常「力動性因子」としてグルーピングされる形容詞群である 9) が、力動性の高い地域も低い地域も、ともに一定の評価を得るよ うである。その理由として、静かな環境を望む人と活気がある環境 を望む人がともに一定数いることや、「静かに暮らしたいが、静かす ぎても治安の心配があるのである程度活気があってほしい」という ような、相反する要望を抱えて人々が居住地を選び取っていること などが考えられる。

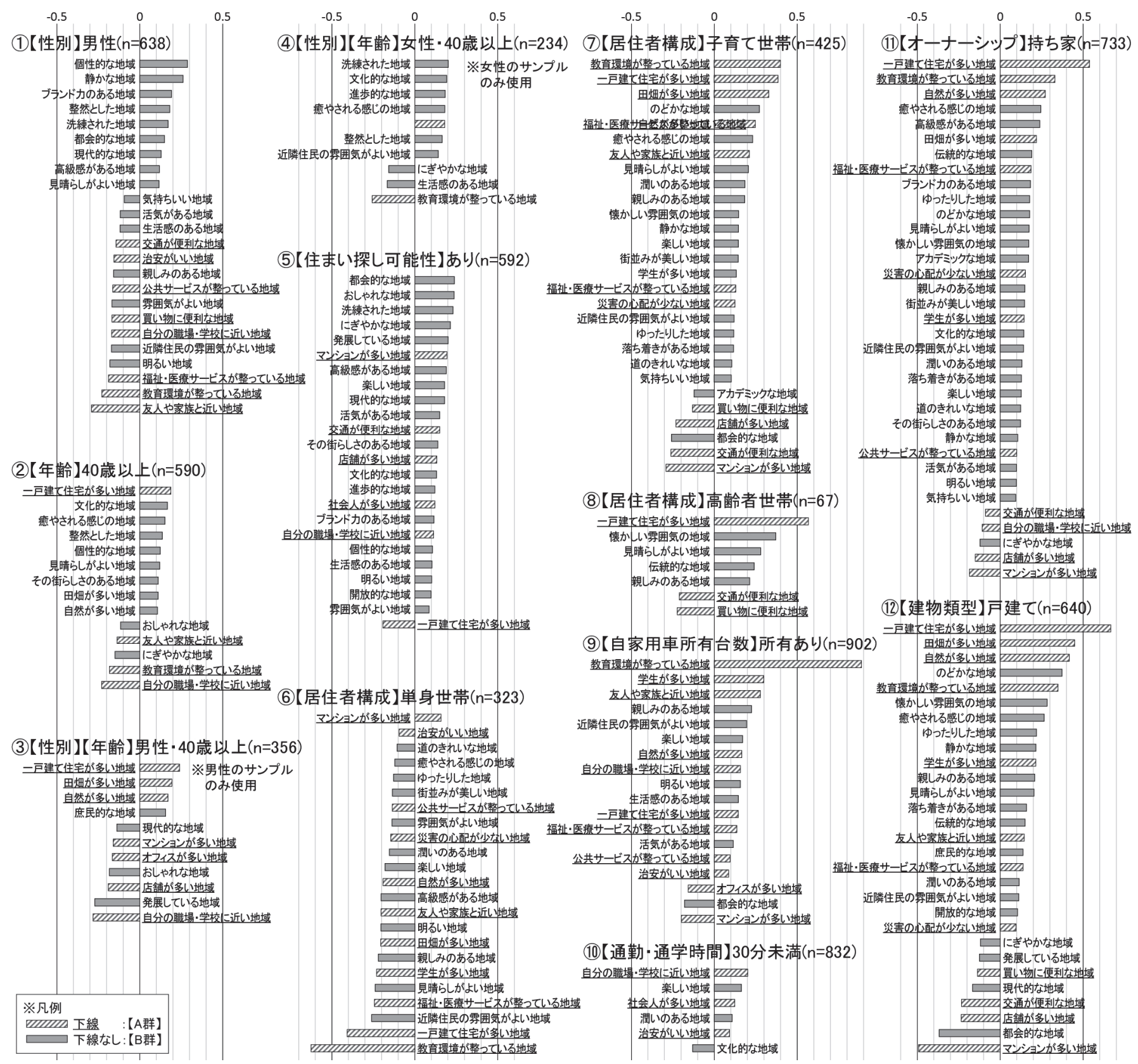

図3属性および将来における居住条件の選択肢別の、居住地選択の際に重視する評価指標

\section{2. 標準偏差について}

次に標準偏差を用いて、各指標における回答の散らばりの度合い を分析する。平均值と標準偏差は逆相関（相関係数 -0.683）の関係 にある。平均值が上位の評価指標は多くの人が共通して望むもので あるが、一方で下位だからといって必ずしも全員にとって重要度の 低い指標であるわけではなく、人によって重視するかどうかが分か れる指標であると言える。【A群】の[友人や家族と近い地域][教育環 境が整っている地域]、【B群】では[おしゃれな地域][ブランド力のあ る地域][高級感がある地域]などが、標準偏差が高い。

どのような地域が居住環境として優れているかとか、どのような 言葉が地域の雰囲気の評価のために適切かとかいったことは、評価 指標データだけからでは一概には判断できない。本章で推測された、 居住地選択における矛盾が内在することや、回答者による選択傾向 の違いがあることなどを作業仮説とし、次章以降に詳しく分析する。

$0.5-100$ 


\section{4. 属性、居住条件に基づく分析}

本章では属性と居住条件の項目ごとに分析する。図3の各グラフ は、属性、居住条件の各項目内で、表題の選択肢（または複数選択 肢のまとまり）を選んだ回答者と、そうでない回答者の間の、評価 指標の平均值の差を表わしている。たとえば図3-11であれば、正の 值は表題にあたる[男性]の回答者がそれ以外の回答者（[女性]）より 相対的に高く、負の值は[女性]が[男性]より高かったことを示す。力 ッコ内に示す $\mathrm{n}$ は表題に該当する回答者数を示しており、また評価 指標はt検定によって差が $5 \%$ 有意となるもののみを抽出した。

\section{1. 属性に基づく分析}

【性別】（図3-(1)）では、[女性]の方が【A群】の評価指標を重視す ることが明確にわかる。女性は特に、治安のよさや安心感、友人や 家族、近隣住民とのコミュニケーションを求めている。一方で[男性] に特徵的な指標は【B群】のみで、しかも図2 2 にいて平均值順位の 低かった[個性的な地域][ブランド力のある地域][高級感がある地 域]といった指標が多く含まれている。女性は安全性や機能性を、男 性は地域の外的なイメージを重視する傾向があると言える。

【年齢】（図3-(2)）については、高齢になるほど自然や癒やし、文 化などを重視する傾向がある。若年層の方が有意に高い指標は、仕 事や就学、子育てをしている割合の高い世代であることが影響して いると思われる。さらに【性別】と【年齢】をクロスし、男女それ ぞれのサンプル内での年齢による有意差を調べたのが図3-(3),(4)で ある。図3-(2)に見られる指標がさらに性差によってセグメントされ ている。年を経るに従い相対的に、男性は利便性や都市性から自然 や癒やしへ、女性は教育環境や安心感から文化性へと、重視項目が 変わることがわかる。時間経過によって、フレームが変化する。

【住まい探し可能性】(図3-(5)主7) に関しては、可能性のある回答 者の方が有意に重視する項目が多数ある。2.2.で指摘した「住まい探 しの可能性がある人の方が、相対的に感度が高いサンプルとなる」 という予想が裏付けられた。住まい探しの可能性のある回答者は、 特に都心志向を思わせる評価指標が多い。頻繁に居住地を変えるの は都心の賃貸居住者が中心になっていることが伺える。

\section{2. 同居者条件に基づく分析}

ここからは現在・将来のデータを用いて時系列での比較分析も行 なう。まず表 3 に居住条件、居住地の全項目での、現在・将来で異 なる選択肢を選んだ回答者の割合「変動率」注8) をまとめる。【居住 人数】【居住者構成】ともに変動率が $40 \%$ 近い值となっており、家族 構成の変化と転居とが結びつきやすいことを示している。ただしこ れには居住地を変えるだけでなく「居住物件」の変更という意味合 いも大きいのではないかと推測される。
表3 項目ごとの現在から将来への変動率

\begin{tabular}{|c|c|c|c|c|c|c|c|c|}
\hline & $\begin{array}{l}\text { 居 } \\
\text { 住 } \\
\text { 数 }\end{array}$ & $\begin{array}{r}\text { 成居 } \\
\text { 住 } \\
\text { 者 } \\
\text { 構 }\end{array}$ & $\begin{array}{l}\text { 所 自 } \\
\text { 有家 } \\
\text { 台用 } \\
\text { 数車 }\end{array}$ & $\begin{array}{l}\text { 時通 } \\
\text { 間勤 } \\
\text { 通 } \\
\text { 学 }\end{array}$ & 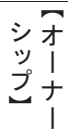 & $\begin{array}{l}\text { 建 } \\
\text { 物 } \\
\text { 形 } \\
\text { 式 }\end{array}$ & $\begin{array}{l}\text { 都 } \\
\text { 市 } \\
\text { 規 } \\
\text { 模 }\end{array}$ & $\begin{array}{l}\text { 地 } \\
\text { 域 } \\
\text { 類 } \\
\text { 型 }\end{array}$ \\
\hline 变動率 & $39.0 \%$ & $39.5 \%$ & $31.6 \%$ & $44.1 \%$ & $30.8 \%$ & $31.8 \%$ & $24.5 \%$ & 52.3 \\
\hline
\end{tabular}

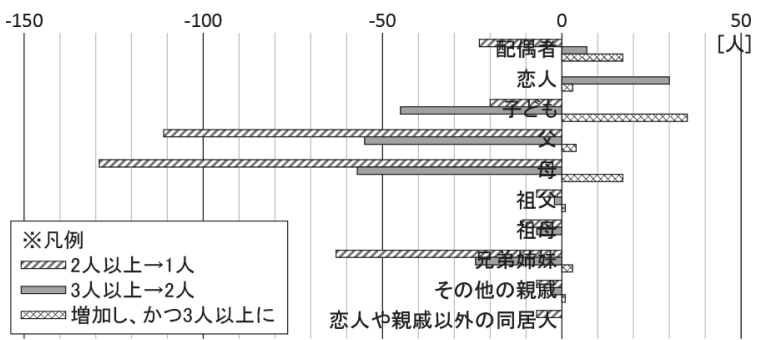

図5

【居住人数】の主要な変化パターンにおける【居住者構成】 の各メンバーの増減（全回答者合計）

図4は【居住人数】の現在・将来での比率とその変化を示している。 現在・将来ともに[1人]（単身）～[4人]で約 9 割を占める。中でも [1 人]と $[2$ 人 $]$ の割合が現在から将来へと大きく増加する。また人数が 増えるケースは 1 人ずつ $([1$ 人 $] \rightarrow[2$ 人 $] 、[2$ 人 $] \rightarrow[3$ 人 $] 、 \cdots)$ がほとん ぞであるのに対し、減少するときは一挙に複数名が減ることが多い こともわかる注9)

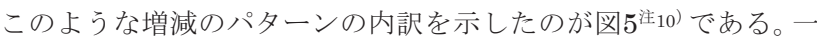
人暮らしになる人は、父母、祖父母や兄弟姉妹などが大きく負の值 となっており、実家を出て血縁家族と離れるケースが大多数である ことがわかる。二人暮らしになる人は、同じく実家から出て恋人や 配偶者と住み始めるケースの他、子どもが家を離れることで両親だ けとなるケースも多い。一方、増加して 3 人以上になる場合は子ども が増加する割合が高く、出産による自然増を示している。父母との 同居の再開というケースもある。

次に将来の【同居者構成】を基に「単身世帯」「子育て世帯」注11 「高齢者世帯」注12) という特徵的な世帯構成を抜き出し、これらに対 する当てはまりの有無による評価指標の違いをグラフ化した（図3(6), (7),8)

単身世帯はそうでない人と比べて有意に值が低い指標が 22 も る。そして子育て世帯はこれと真逆に近い傾向を示寸。教育環境を はじめとした緒サービス、安心感や親しみ、雾囲気のよさなどに単 身者はほとんど関心をもたないのに対し、子育て世帯は重視する。 また単身者が集合住宅、子育て世帯が一戸建て住宅を志向する傾向 もはっきりしている。高齢者世帯はサンプル数が少ないものの、郊 外の戸建て志向という意味では子育て世帯から変わらない。

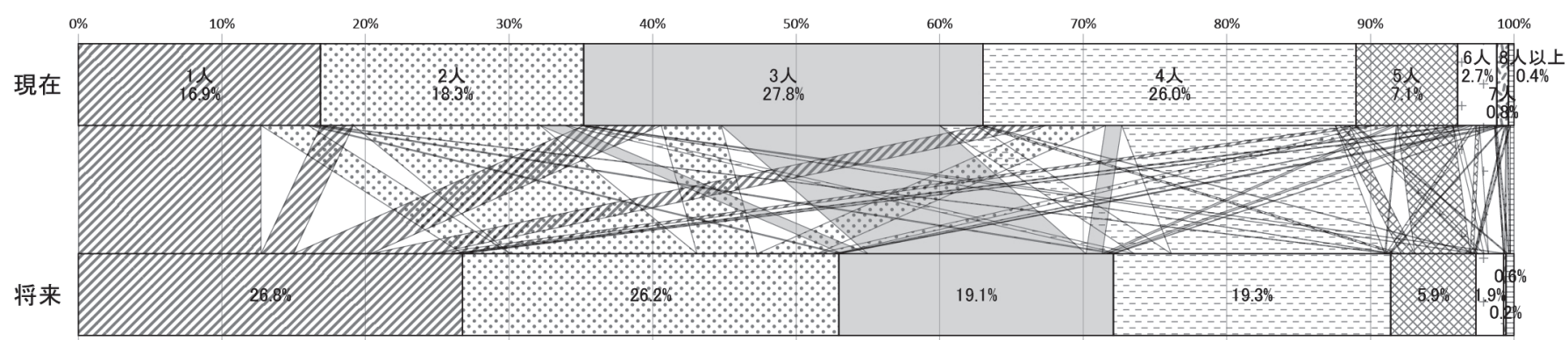

図4【居住人数】の現在と将来の選択肢の割合の変化 
以上より、「若い頃はワンルームマンションに住み、結婚して子ど もが生まれたら郊外一戸建てに移り、やがて子どもが独り立ちし、 郊外で一生を終える」という典型的なわが国のライフコースが見え てくる。バブル期にマイホーム神話が崩壊し、近年では晚婚化と少 子化、高齢者の都心回帰などの動きも見られるが、ライフコースの プロトタイプは上田が「住宅双六」10）を発表した高度成長期から大 筋では変化していないと言える。その中で、単身から結婚、子育て の開始に至る短期間で、求める居住地像が急激に変化する。

\section{3. 交通条件に基づく分析}

図6は【自家用車所有台数】、図7は【通勤・通学時間】の、現在・ 将来の推移を示している。車の所有台数は[1台]が半数近くを占め、 現在から将来へと減少傾向にある。居住人数】は増加方向と減少方 向に傾向の違いがあったが、【自家用車所有台数】の変化は増減とも に1台単位が主となっている。

【通勤・通学時間】は、現在は[10分未満]～[30分〜1時間]で半数を 占め、将来になるとこの部分がさらに増加する。[10分未満]に短縮 したいという回答者はごく少数である。反対に 1 時間以上かかる回 答者が現在では 1 割程度いるが、そのほとんどが、1時間以内に短縮 することを望んでいる。

次に将来の自家用車の所有の有無と、通勤・通学時間が 30 分以内 か否か注13) による評価指標の違いを示したのが図3-(9),(10である。自
家用車の所有の有無には、郊外志向と都心志向というコントラスト がはっきりとあらわれている。一方で通勤・通学時間については明 確な傾向は見られない。郊外戸建て指向者も、都心指向者と同じく 短い通勤時間を望んでいる。勤務地の都心集中傾向のある現在のわ が国では、この条件を満たす居住地を探すのは難しいと思われる。

\section{4. オーナーシップ、建物類型に基づく分析}

図8は【オーナーシップ】と【建物類型】をクロスさせた上での現 在・将来比較を示す。現在は[持ち家]と[賃貸]が $6: 4$ の割合であるが、 [持ち家]においては[一戸建て]が、[賃貸]においては[集合住宅]がそ れぞれ8割前後を占める。将来にかけての変動率は $30 \%$ 程度あり、や はり[持ち家]の[一戸建て]と[賃貸]の[集合住宅]の間の出入りが多い。 4.2 で見られた、実家から出るパターンと結婚して世帯を設けるパタ ーンがこの出入りの多くを占めると考えられる。ただし【オーナー シップ】【建物類型】の割合構成には大きな変化はない。

【オーナーシップ】と【建物類型】それぞれについて評価指標の有 意差を見ると（図3-(11),12)，[持ち家][一戸建て]は郊外子育て層、[賃 貸][集合住宅]は都心単身層の傾向と類似する。

\section{5. 都市・地域に関する分析}

本章では【都市規模】【地域類型】（現在および将来）と、評価指 標データを用いた分析を行なう。これまでの居住地選択の研究に照

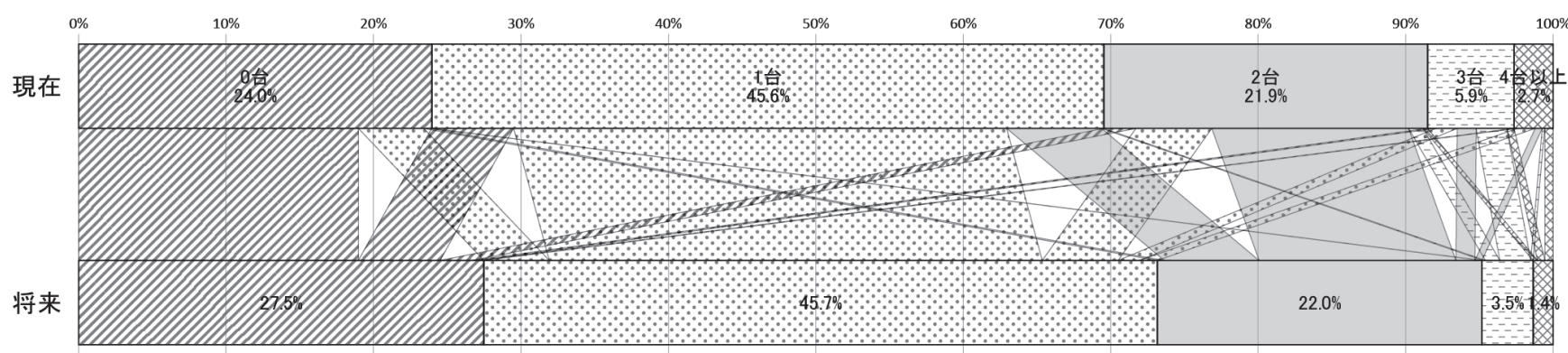

図6【自家用車所有台数】の現在と将来の選択肢の割合の変化

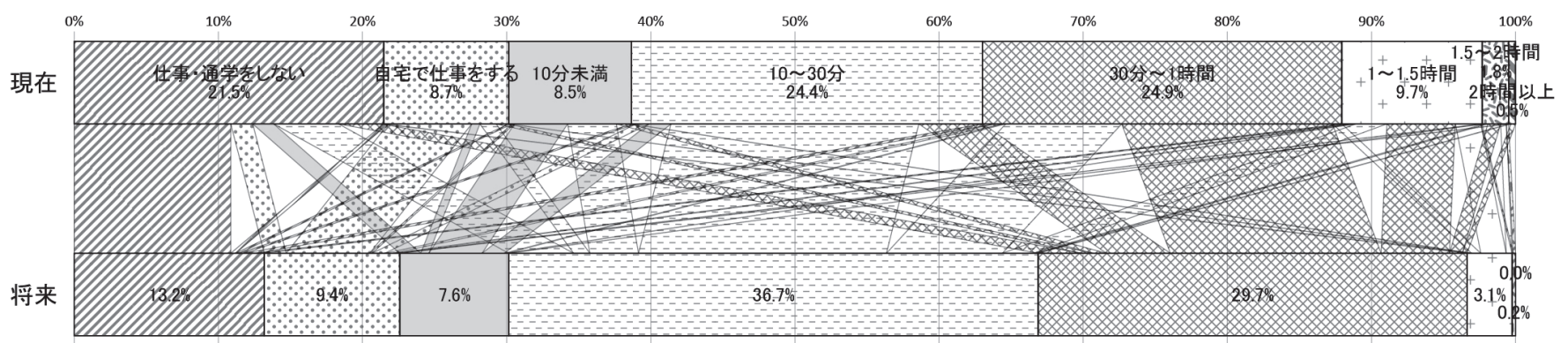

図7【通勤・通学時間】の現在と将来の選択肢の割合の変化

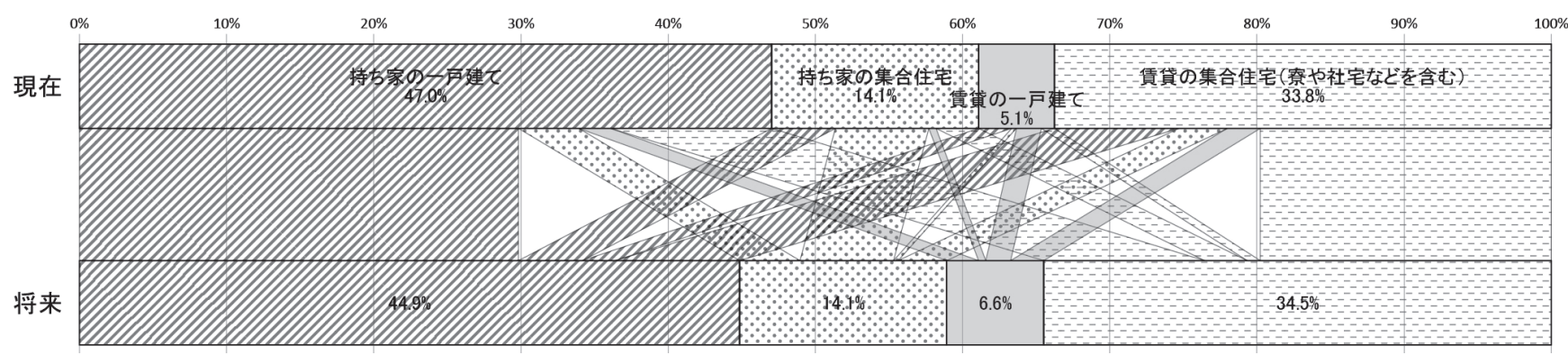

図8【オーナーシップ】【建物類型】の現在と将来の選択肢の割合の変化 


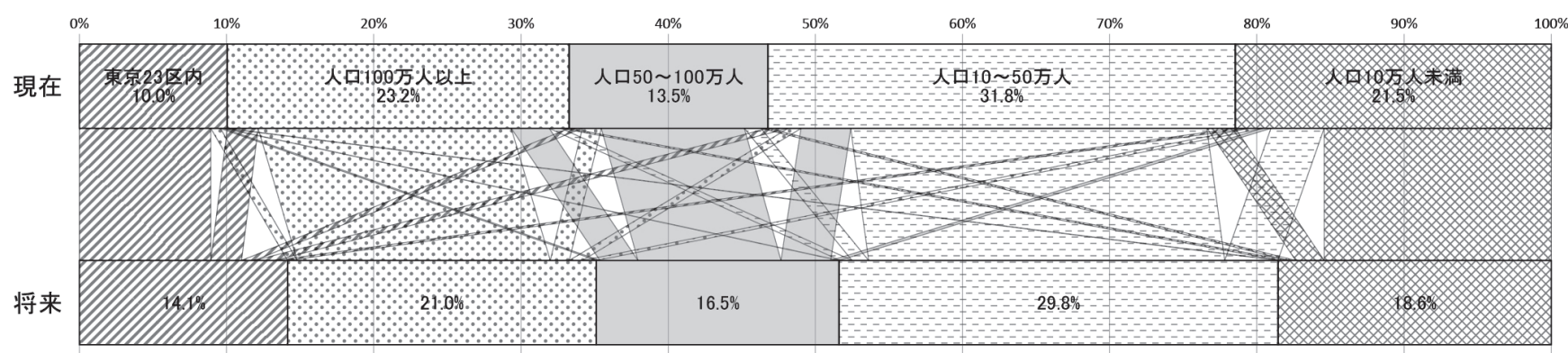

図9【都市規模】の現在と将来の選択肢の割合の変化
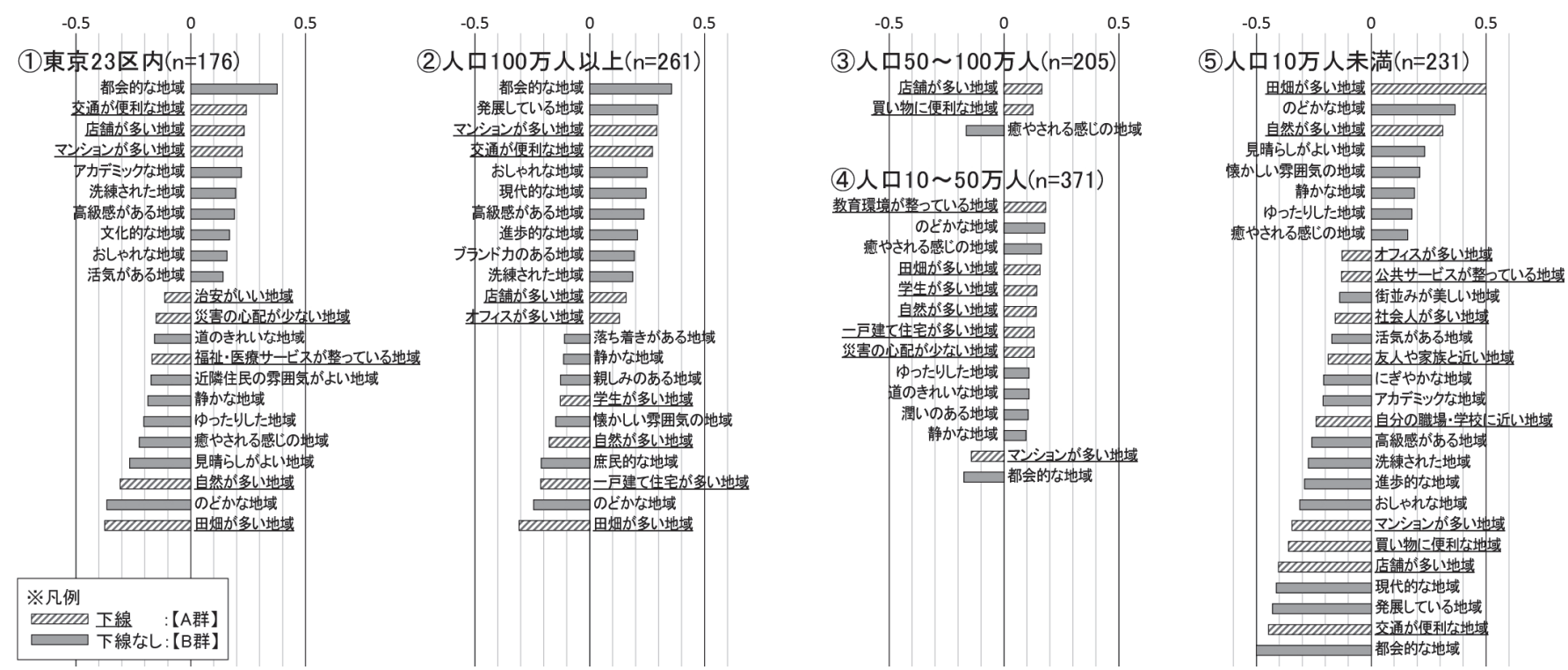

図10 将来における【都市規模】の選択肢別の、居住地選択の際に重視する指標

らすと、【都市規模】は各都市を単位とした人口動態論的な視点に、 【地域類型】は都市内のゾーニングに対応した機能論的視点にそれぞ れ対応する。これに対して評価指標は個人を単位とし、かつ雾囲気 などを含む全体的な現象を扱う様相論的立場に立脚したデータであ る。本章はこれら三つのデータの間にある関係性を分析する。具体 的にはまず、【都市規模】【地域類型】について前章と同じく現在・ 将来比較と選択肢別に重視される評価指標を調べる。最後に、【都市 規模】【地域類型】のクロス分析を行なう。

\section{1. 都市規模}

図9は【都市規模】の現在・将来比較である。現在は[人口 $10 \sim 50$ 万人]の中規模都市の居住者が最大の割合を占めることがわかる。将 来への変動については、表 3 より【都市規模】の変動率は $24.5 \%$ と他 の項目と比べて最も低く、基本的には都市規模を変えずに、あるい は同一市町村内で住み続けたい人が多い。移動を想定する回答者の 内訳は、[人口10万人未満]からは[人口10～50万人]へ、そこからは [人口50〜100万人]へといったように、現在居住しているよりも一段 階上の規模の都市への転居を望む回答者が多い。ただしその傾向は [人口 $50 \sim 100$ 万人]と[人口 100 万人以]の間でだけは見られず、後 者から前者への移動が多い。その結果、図9の数值でも [東京 23 区内] と[人口50〜100万人]だけが伸びを示している。人口 50 〜 100 万人の 範囲には、新潟市や熊本市、岡山市などの地方中核都市が含まれる。

図10は、将来の選択肢ごとに重視する評価指標をグラフ化したも のである。[東京 23 区内]および[人口 100 万人以上では、都心志向の
指標が集まる。ただし利便性を示す指標としては[交通が便利な地 域]のみで、それよりも「都会的でおしゃれで洗練されている」とい う、大都市の雾囲気や文化が魅力となっていることが注目される。 [人口 $10 \sim 50$ 万人][人口 10 万人未満]では大都市のグラフを反転させ たような傾向がある。特に後者では明確に、のどかでゆったりとし た雰囲気の住環境を求める人が集中寸る。大都市の市域にも戸建住 宅街は存在し、小都市にも中心市街地はあるのだが、「大都市＝中心 地、小都市二郊外住宅地」というイメージが強いことがわかる。

一方で、図9において将来への増加傾向があった[人口 $50 \sim 100$ 万 人]では、有意差のある評価指標が少ない。大都市志向と小都市志向 の中間にあるためだと考えられる。大都市と小都市、中心地 (都市) と郊外（農村）の対比は都市地域論の基本的なモデルであるが、地 方中核レベルの都市は、両方の魅力を併せ持つものとして認識され ていると考えられる。

\section{2. 地域類型}

表3より、全項目の中で最も変動率が高い $(52.3 \%)$ 【都市規模】 とは対照的な結果である。選択肢の数自体が 10 と多いのもその一因 であろうが、現在の居住地に住んだ結果、同じような規模の都市 (あ るいは同一の市町村内）でも別のタイプの地域に移りたいという希 求が生じていると見ることができる。

現在と将来の比較を図11に注14)、選択肢ごとに重視される評価指 標を図 12 に示す。現在では[庭あり戸建地域]に住む人が最多で、[庭 なし戸建地域]と併せて約半数を占める。[都心地域]と[農・山・漁村] 
はそれぞれ $3 \%$ 程度と少ない。

将来に向けて大きな伸びを見せるのが、回答数の少ない[別荘・リ ゾート]を除けば、[都心地域]と[繁華街地域]である。まず[都心地域] の評価指標は、【都市規模】の大都市と同じ傾向が見られる。[繁華 街地域]では買い物や交通、公共サービスの利便性が評価され、また 「都会」や「発展」というイメージと、「雑多」や「庶民的」という
イメージとが入り混じっている。

逆に現在から将来へと目立ってマイナスが大きいのが、[庭なし戸 建地域]、[住工混合地域]である。これらの地域では、評価指標で全 ての值が負となっており、またほとんどが【B群】の指標である。こ うした地域を選択するのは、利便性は標準程度に求めるが、街の活 気や美しさには関心を抱かないタイプの人であると読み取れる。高

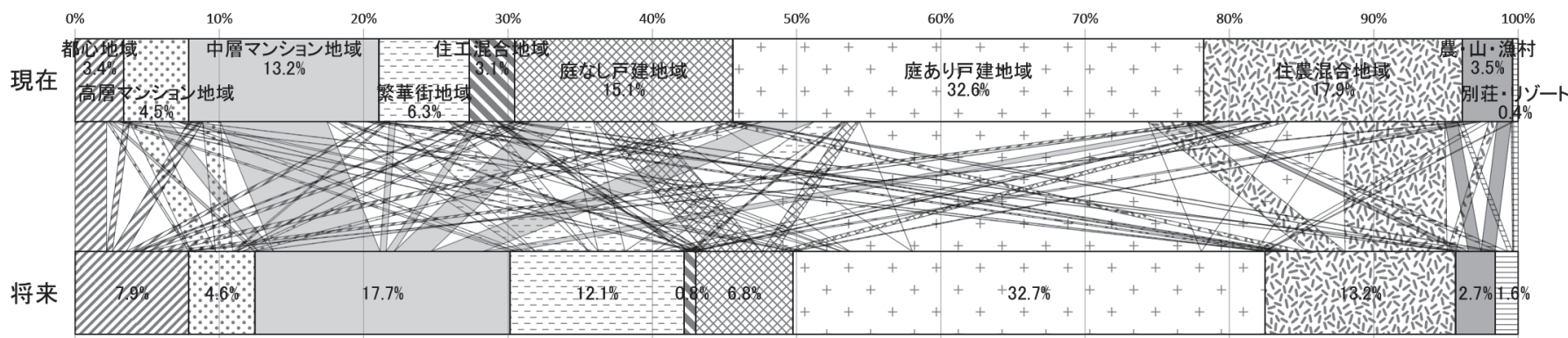

図11【地域類型】の現在と将来の選択肢の割合の変化

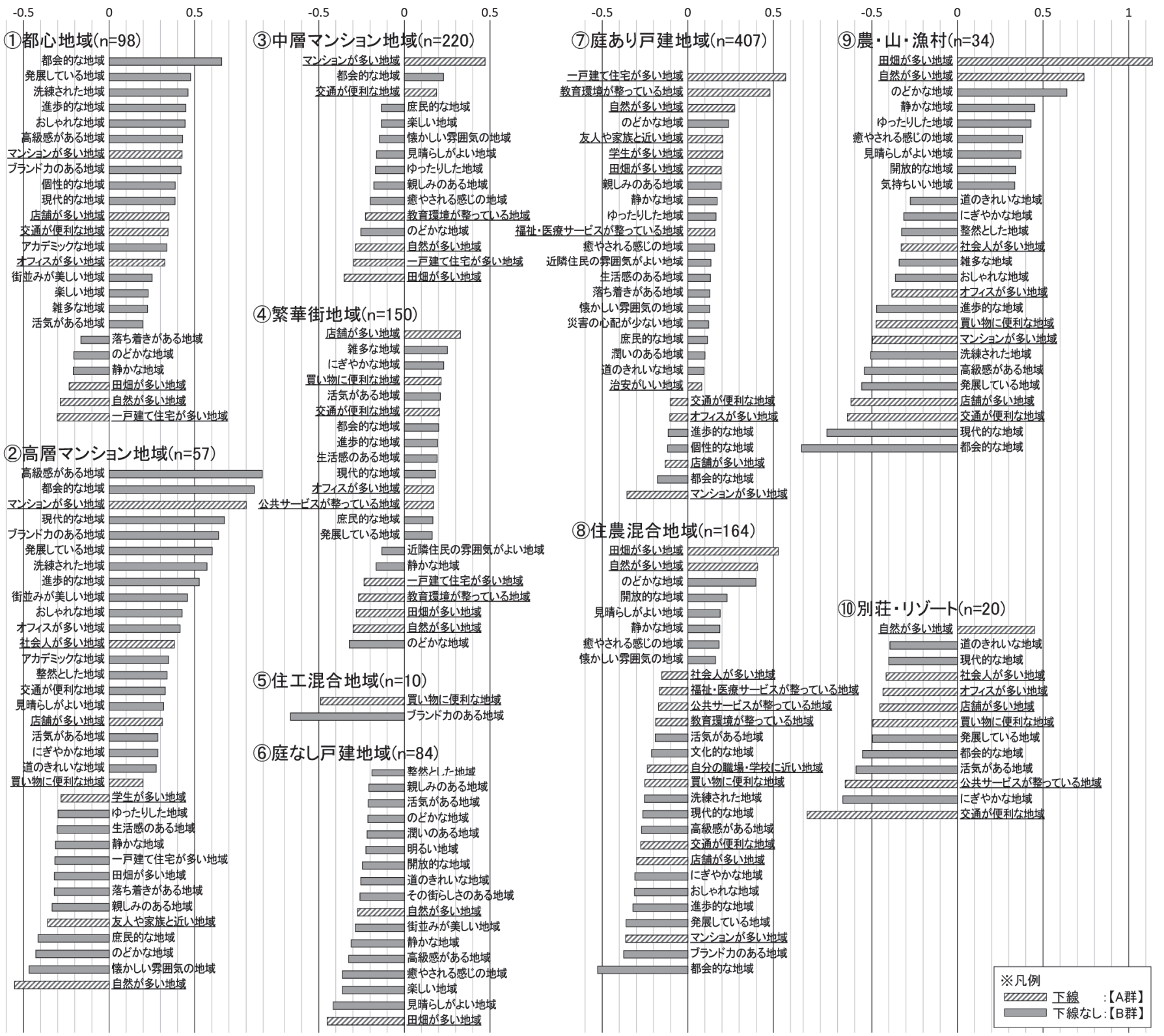

図12 将来における【地域類型】の選択肢別の、居住地選択の際に重視する指標 
度成長期の無秩序な開発やバブル期のミニ開発などが住環境の悪化 を招いているものと推測される。

マンションの多い地域では、[高層マンション地域]は現在から将 来にかけてほぼ増減がなく、[中層マンション地域]は増加する。後者 は[庭あり戸建地域][庭なし戸建地域]からの転出者の主要な受け血 となっている。評価指標では、[高層マンション地域]は都心のもつブ ランド力や利便性を享受できる地域と見做されている。一方[中層マ ンション地域ににはそのようなブランド意識はなく、どちらかという と[庭なし戸建地域] と傾向が似ている。そこまで周辺環境にはこだ わらないが、マンションに住みたいという人が集まる地域である。

現在で最大の割合を占める[庭あり戸建地域] 、将来でもほとん ど割合が変わらない。[中層マンション地域]や[繁華街地域]への流出 があるものの、[庭なし戸建地域]や[住農混合地域]などから流入があ り、バランスしている。評価指標を見ると子育て世帯（図3-(5)）と 共通するものが多い。

[住農混合地域]、[農・山・漁村]にも減少傾向が見られる。評価 指標では都心と逆の傾向を示し、のどかでゆったりとした䨌囲気が 評価されながらも、利便性に関する指標愩の值をとる。自動車依 存や公共サービス、福祉・医療サービスの不足はこうした地域の課 題であるが、そうした点を重視しない人がこれらの地域を選択する。

\section{3. 都市規模と地域類型とのクロス分析}

最後に、【都市規模】と【地域類型】の関係を分析する。図13は【都 市規模】別の【地域類型】の内訳である。

全体の傾向としては、やはり「大都市＝中心地、小都市＝郊外住 宅地」に重心がある。ただし、以口10万人未満]での[庭あり戸建地 域]の割合は、[人口10～ 50 万人]でのそれよりもむしろ縮小する。図 12で[庭あり戸建地域]は[住農混合地域]や[農・山・漁村]に比べると 相対的に利便性が重視されており、その立地のためには[人口10〜 50 万人程度の都市規模が望ましいものと考えられる。

また図 9 で将来に向けて数值を伸ばした[人口 $50 \sim 100$ 万人]では、 大都市志向と[庭あり戸建地域]や[住農混合地域]がバランス寸る他、 [繁華街地域]も多い。一方図 9 で減少傾向にあった[人口 100 万人以 上]では、[高層マンション地域]、[中層マンション地域]の多さが目 立つ。前節で見たように[中層マンション地域]はやや雾囲気などの イメージが低い地域である。[人口50〜100万人]と比べ、大都市の魅 力にも小都市の魅力にも欠けると言えるかもしれない。

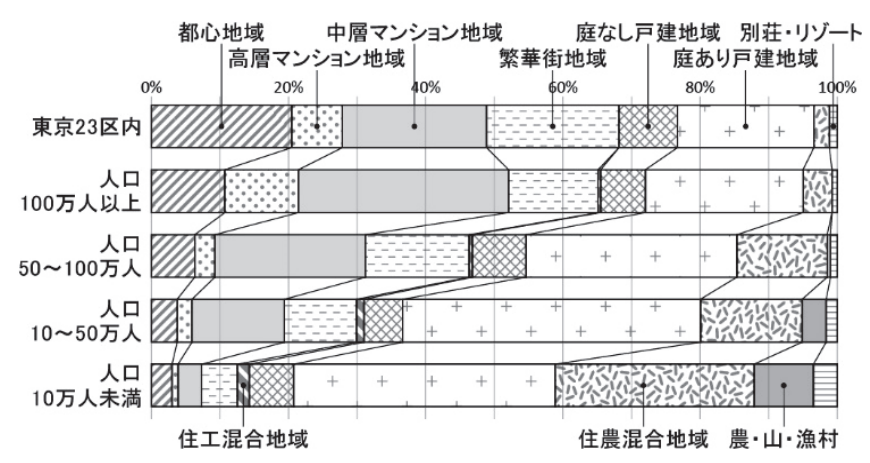

図13 将来の【都市規模】別の【地域類型】の内訳

\section{6. まとめ}

\section{1. 本稿の結論}

本稿では以下のことが明らかになった。

・1章では、居住地選択を様相論的に研究するという新規の試みにつ いて、理論的枠組みと方法論を提示した。それに従い 2 章で調查方 法を実装・実施し、3章以降で分析を行なった。分析によって以下 の項目のような一定の成果が得られていることから、本研究の理 論的枠組みと方法論の有効性が示されたと考えられる。

·3章より、居住地選択の際の判断基準として利便性などの従来的指 標だけでなく、雾囲気に関する諸指標も重要であることがわかっ た。また 4,5 章では、その諸指標から属性、居住条件、居住地の選 択肢による差をつくりだすものを見出した。「都会的・ブランド」 「安心・便利」「郊外・明るい・教育」「自然・のんびり」などのま とまりがそれに当たる。

・4章では、「属性」「居住条件」とそれによる居住地選択傾向を明ら かにした。特に【性別】や【年齢】【住まい探し可能性】【同居者 数】【オーナーシップ】【建物タイプ】などが選択傾向に大きな差 をもたらす。また「都心・単身・自動車所有なし・集合住宅・賃 貸」「郊外・子育て・自動車所有・戸建て・持ち家」がそれぞれ密 接に関連し、結婚や子育てを機に選択傾向が大きく変わることを 示した。ただし【通勤・通学時間】はこれらの傾向と関係が薄い こともわかった。

• 5 章において、人口動態論的視点、機能論的視点、様相論的視点を 掛け合わせて総合的に居住地選択傾向を分析した。上述のように 都心と郊外は居住地選択の主要な極であるが、【都市規模】で人口 50〜100万人の都市がこの両方の魅力を併せ持つものである可能 性を指摘した。都市内の【地域類型】においては好まれる地域と そうでない地域が比較的明瞭に分かれることがわかり、また【地 域類型】ごとに特徵的な評価指標が明らかになった。

これらの知見は、1.1.で示した住まい探しの方法の改善と、居住地 の評価指標の構築に向けて極めて有用だと考えられる。

\section{2. 都市と地域の動向}

本稿の調查で得られたデータには、回答者の願望が多分に反映さ れてはいるものの、わが国の都市や地域が今後どのように変わるの かを予測するデータにもなっている。人口減少の局面に入り、農山 漁村、狭小住宅街や住工混合地域などは、長期的に見れば衰退する 可能性があるだろう。

そのような時代にあっても、若い頃は都心の賃貸集合住宅で単身 居住し、子育て期には郊外の一戸建てに移り、老後もそこで暮らす というライフコースが典型的なようである。根強いフレームとして、 居住地選択に影響を与えている。

こうしたフレームは人が環境から独立で形成したものではなく、 実際の居住体験を重礼てつくってきたものだ。しかし居住環境も、 われわれがそのときどきのフレームに則ってつくりあげてきたもの である。居住環境とフレームは、一体となってつくられ、また変化 してきたのである。ただし郊外の一戸建て生活も主流となったのは ここ 50 年来で、ワンルームマンションというビルディングタイプも 1980年代以降のものである。今後も価值観、経済や技術などの変化 により、新しい住まい方や地域類型が生じる可能性がある。

\section{3. 今後の課題}

本研究の今後の課題として、以下のものがある。

・本稿は方法論の構築と、わが国における全般的な傾向の分析を主 
眼としており、得られた成果もその範囲に留まる。今後は本稿で 得られた、重要度の高い指標や居住条件に関する知見を活用して、 実際の都市・地域をフィールドとしたデータを取得し、地理的分 析を展開する。それにより周辺地域との関係性や都市構造、都市 の歴史などに踏み込んだより深い分析が可能となる。

・本稿では注2)で示したように、金銭的条件を分析から除外した。 たとえば本稿では【地域類型】の動向には極端な傾向が見られた が、実際の人口の動きには金銭的条件がある程度歯止めをかける ものと考えられる。金銭は重要な評価方法の一つであり、本稿で 得られた評価指標との関係性を分析寸る必要もある。

・本稿で示されたのは全体の傾向であり、少数の新しい動きを把握 できていない。そうした動きは今後の主流となって住まい方を大 きく変える可能性があり、研究に值する。

\section{謝辞}

本研究は、「100ninmap project」および「住まい探し支援を目的 とした街の雰囲気情報の可視化に関寸る研究」の一部として行なっ たものです。共同研究者各位、特に今回の調查・分析にご協力いた だいた清田陽司氏（株式会社ネクストリッテルラボラトリー）、荒 牧英治先生 (奈良先端科学技術大学院大学 研究推進機構) 、若宮翔 子氏（同）、宮部真衣先生（和歌山大学 システム工学部）に深く感 謝いたします。

\section{参考文献}

1）原広司：空間〈機能から様相へ〉，岩波書店，1987, p.224.

2) 北雄介・門内輝行 : 経路歩行実験による都市の様相の記述一都市の様相の 解読とそのデザイン方法に関する研究 その 1 , 日本建築学会計画系論文 集, Vol.75・No.651, pp.1159-1168, 2010.5.

3）北雄介・門内輝行 : フレーム概念に基づく都市の様相の分析とモデル化一 都市の様相の解読とそのデザイン方法に関する研究 その 4 , 日本建築学 会計画系論文集, Vol.79・No.696, pp.421-430, 2014.2 .

4）清水伸幸・中川雅史 : マイクロタスク型クラウドソーシングの現状と課題 一実際の運用の知見から一, 情報処理, Vol.56, No. 9, pp.886-890, 2015.

5）西山悠介-中谷隼 - 栗栖聖 - 荒巻俊也 - 花木啓祐：居住地属性の住民選好

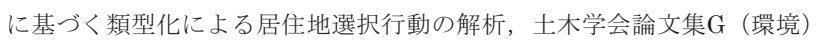
67(6), pp.II_1-II_10, 2011.

6）鶴崎直樹・坂井猛・上野武・有馬隆文 : 学生の居住地選択の嘹好に基づく 居住環境評価に関寸る基礎的研究, 都市 - 建築学研究:九州大学大学院人 間環境学研究院紀要, Vol.9, pp.45-51, 2006.

7）船越徹・積田洋：街路空間における空間意識の分析（心理量分析）, 街路 空間の研究 その1, 日本建築学会論文報告集, No.327, pp.100-107, 1983.5.

8）室恵子・須永修通・伊藤直明 : 居住環境評価のための用語の特性に関する 考察, 心理評価の抽出方法に関する研究 4 , 日本建築学会計画系論文集, No.534, pp.69-75, 2000.8.

9) Osgood, C.E., Suci, G.J. and Tannenbaum, P. : The Measurement of Meaning, University of Illinois Press, 1957.

10) 上田篤：現代住宅双六，朝日新聞，1973.1.3.

11) Altman, I. and Rogoff, B. : World Views in Psychology: Trait, Interactional, organismic, and Transactional Perspectives, Stokols, D. \& Altman, I.(ed.), Handbook of Environmental Psychology, John Wiley \& Sons, 1987, Chap.1, pp.7-40.

\section{注}

注1）http://crowdsourcing.yahoo.co.jp/

注2） 1.2.で触れたように、住まい探しにおいて居住条件や居住地は「制約」 として与えられる側面と、自らが主体的に「希望」や「好み」を反映できる 側面とをもつ。したがって居住条件、居住地の将来の質問は「制約の下で 選択する」という表現と「意志的に希望する」という表現との間の中性的 な、「想定する」という表現を用いている。指標はより能動的な評価の側面
を持たせるため、「重視する」という表現とした。

また居住地域や物件を決める際、現実的には物件の価格や賃料などの金銭 面が判断の大きなウェイトを占めることになる。しかし金銭は、物件 (家、 部屋）とその環境となる都市・地域との全体に対して支払われるものであ り、都市・地域だけを切り離せない。また特に指標の回答に対して金銭条 件が影響する可能性がある。居住地選択と金銭との関係は興味深い課題で あるが、本稿ではそこには立ち入らない。

注3） 1.4.で述べた既往研究などを参照した。ただし既往研究と本研究では文 脈が異なるため、本研究で独自に設定しているものも多い。

指標は、「地域」を語尾につけることで表現を統一した。また住まい探しの 際に重視することを知るために、似た意味を表わす単語がある場合は、一 般的にポジティブなイメージだと考えられる表現を選定した（例：[うるさ い地域]ではなく[にぎやかな地域]）。

注4）「客観群／主観群」などと呼ばないのは、筆者が客観的データと主観的 データははっきりと弁別できないという立場を取るからである。既往研究 では、客観的に把握される物理環境を尺度化したく物理量 $>$ と、人間が知 覚する感情や感覚を尺度化した<心理量 $>$ を明確に分け、これらの間での 相関性を分析する研究が広く行なわれてきた（文献7など）。心身二元論に 基づく明快なアプローチであるが、トランザクショナリズム等の立場から の批判も行なわれている（文献11など）。筆者のとる様相論的アプローチ では、これらを明確には区別しない。

注5）実際には、「Yahoo!クラウドソーシング」のタスク設定の制約上、「属 性、居住条件、居住地」と、「指標」とで分割してデータを取った。また若 年層のサンプル数が不足していたため、20代以下限定で追加調査を行なっ た。 $\mathrm{N}=1,244$ は、これらの調査で全質問項目に回答したサンプル数の合計 であり、指標について回答していないサンプルなどは除いている。

注6）【職業】は簡明な分類が難しく、 4 章で行なう評価指標の平均值比較 分析に適さないため、本稿の主な分 析対象からは省く。なお【職業】の 内訳は右図のようになっており、【年 齢】の偏りに対応して学生数が少な い。

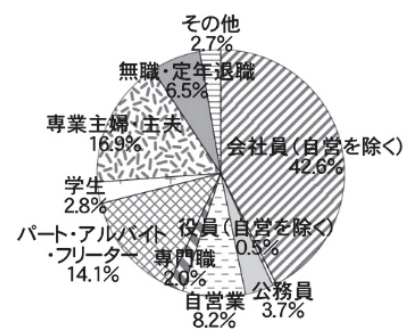

注7） 3 年以内の住まい探しが[ほぼ決定している][可能性がある]とした回答 者を「可能性あり」として、[可能性はない]とした回答者を「可能性なし」 としている。

注8）複数選択可の【同居者構成】については、構成が現在・将来で完全一致 するか否かで変動の有無を判断している。

注9）図3を見ると、【同居者人数】は現在から将来へと明らかに減少してい るように見える。ただ4.2.で述べたようにこれは実家からの独立が主な要因 であり、転居する当人以外の家族は実家に残っている。したがって図3を、 現在のわが国の人口減少や世帯あたり人数の減少と結びつけるのは早計で ある。またこのデータには転居と同時期に起こる同居者人数の増減は加味 されているが、それ以外のタイミングでの自然増や自然減は考慮されてい ない。この点については、以後の分析でも同様に注意を要する。

注10）「増加し、かつ 3 人以上に」には、現在が既に 3 人以上の場合（たとえば 現在 $[3$ 人] $\rightarrow$ 将来 $[4$ 人]）も含まれる。

注11）将来において本人が50歳未満でかつ子どもと同居する回答者の世帯を 「子育て世帯」とする。

注12) 将来において(1)本人が祖父母のいずれかと同居、(2)本人が 40 歳以上で 父母のいずれかと同居、(3)本人が 65 歳以上、のいずれかに該当する回答者 の世帯を「高齢者世帯」とする。

注13）将来において[仕事・通学をしない][自宅で仕事をする]と答えた回答者 は除外している。

注14）アンケートでは回答者が理解しやすいように、[近代的なオフィスや店 舗も多い都心エリア][高層マンション（11階以上）の多いエリア][中層マン ション（10階以下）の多いエリア][小規模な店舗の多い繁華街エリア][工場 の混じった住宅エリア][庭のない一戸建住宅の多いエリア][庭のある一戸 建住宅の多いエリア][田畑や空き地の混じった住宅エリア][農村・山村・漁 村][別荘地・リゾート地]という選択肢を使ったが、本稿では略称を用いる。 なおこの10分類は、用途地域をもとに検討・作成した。 


\section{ANALYSIS ON RESIDENTIAL LOCATION CHOICE AND ITS EVALUATION INDEXES BASED ON MODAL THEORY}

\section{Yusuke KITA*}

* Lect., Unit of Design, Center for the Promotion of Interdisciplinary Education and Research, Kyoto Univ., Dr.Eng.

On visiting real-estate agents or real-estate information websites, we can easily get information on houses or rooms, but it is difficult to know more about the city or area in which the houses or rooms are located. Particularly, it is difficult to determine the atmosphere and comfortability of the area. On the other hand, cities and areas are to be strictly chosen as population decreases. It is necessary to understand how cities and areas are evaluated and how they change in the future for planning them. This paper aims to determine the tendency of residential location choice and evaluation indexes of the choice including atmosphere and comfortability using a questionnaire survey.

This paper applied modal theory for the analysis. We defined the concept of "modality" as "total mode of being." This theory enables us to analyze residential location choice from comprehensive viewpoints, treating both quantitative information like transportation or facility location and vague information like atmosphere or comfortability as equal evaluation indexes. Moreover, we assumed a process model of residential location choice based on the modal theory: a person grasps modality in his/her daily life, and takes background into consideration like his/her own property, memory, conditions of seeking houses or rooms, preference and so on, then chooses a concrete residential location.

The survey items included "property" of the residents, "housing conditions" like family structure and transportation, "residential location" shown as urban scale and area type, and "evaluation indexes" for the location. The housing conditions and residential location were asked for both the present and future expected residence in order to analyze the process of making choices and the future trend. As for evaluation indexes, we selected 53 indexes that involved both convenience and facility location, and atmosphere and comfortability. The survey was conducted in June 2016, and 1,244 samples were collected through the survey.

Chapter 3 analyzed "evaluation indexes." We found that not only existing indexes like convenience and facility location but also those like atmosphere and comfortability were highly valued in choosing a residential location. Additionally, we made clear that some indexes are important because most residents put weight on them but other indexes are also important as they make significant differences between residents.

In Chapter 4, we added "property" and "housing conditions" into our analysis. The main analysis methods included extracting highly evaluated indexes based on property and residential conditions, and visualizing the change of residential conditions from the present to future. The analysis made clear that males tend to prefer urbanized areas with good public image and females like safe and convenient areas. Families with children preferred to live in detached houses in suburban areas that have good education level. Single households had an opposite tendency toward childraising families.

Chapter 5 analyzed "residential location" using the same methods as in the previous chapter. We found that the population tends to move to bigger cities in the future, but cities with 0.5-1 million people can be a good size with a fascination for both urban and suburban areas. As for area type, urban cores, small shopping districts, and areas with middle-size apartment buildings will become more popular. On the other hand, residential areas without gardens and mixed areas of houses and factories are lowly evaluated as a living environment.

These results are valid as information for house hunters and future urban planning. We plan to develop this study by introducing financial conditions and actual area for concrete analysis. 